\title{
12
}

\section{Making the Right Decision: Justice in the Asylum Bureaucracy in Norway}

\author{
Tone Maia Liodden
}

\section{Introduction}

Asylum decision-making inherently involves high stakes: when asylum seekers present their story to an immigration officer, they place their lives in the hands of another country's authorities. Making a wrong decision can, at worst, be fatal. The decisions are under constant debate in the media, as immigration authorities are criticised either for wrongly rejecting genuine refugees or for admitting bogus asylum seekers. The public debate is characterised by disagreement, strong emotions and conflicting ideas about justice. In this chapter, I explore what justice looks like from the point of view of some of the individuals who make these difficult decisions daily, namely caseworkers in the Norwegian Directorate of Immigration (UDI). What are the main challenges involved in making just decisions? What does 'justice' mean to the caseworkers who decide claims? And finally, how does the production of justice inside the institution relate to public expectations of refugee protection? The goal is to investigate some of the underlying normative

This chapter is based on the doctoral dissertation, 'The burdens of discretion. Managing uncertainty in the asylum bureaucracy' (Liodden 2017).

T. M. Liodden ( $\square)$

The Work Research Institute, Oslo Metropolitan University, Oslo, Norway e-mail: tone.liodden@oslomet.no 
issues that are played out in the process of assessing asylum applications, and to consider the relationship between justice, discretion, and bureaucratic goals and values.

Refugee protection holds symbolic value to most democratic states, as refugee rights are based on liberal-universal notions of justice that are important to the identity of democracies (Boswell 2005). There is a deep tension between the wish of European states to adhere to their human rights commitments, while limiting migration as much as possible (Carling 2011). This tension means that asylum decision-makers have to handle two seemingly contradictory goals in their daily work. On the one hand, they have to ensure that bona fide refugees are accorded their rights through protection. On the other hand, they have to maintain control and restrict entry of those not considered eligible for refugee status. The main task of caseworkers is to make correct distinctions among applicants, or in other words, to accord justice to the right group of people.

The analysis in this chapter is based on 24 interviews with UDI caseworkers. The data collection process was guided by principles of institutional ethnography (Smith 2005), which is an inductive method of inquiry that takes the experiences of a particular group of people as a point of departure for exploring an institution. The focus of the inquiry is thus not on individuals, but on the institution (McCoy 2006). The experiences of the interviewees serve as a window to understanding institutional processes that shape the perception of justice in the asylum bureaucracy.

\section{Uncertainty and Discretion in the Decision- Making Process}

Under the Norwegian Immigration Act of 2008, paragraph 28, a foreign national should be recognised as a refugee if he or she thas a well-founded fear of being persecuted for reasons of ethnicity, origin, skin colour, religion, nationality, membership of a particular social group or for reasons of political opinion', ${ }^{1}$ or 'faces a real risk of being subjected to a death penalty, torture or other inhuman or degrading treatment or punishment upon return to his or her country of origin' (Ministry of Justice and Public Security

\footnotetext{
${ }^{1}$ The word 'race', which is used in the Refugee Convention of 1951, was replaced in the Norwegian law in 2011 by 'ethnicity', 'origin' and 'skin colour' (Stortinget 2011). Similar changes have been made in legislation on discrimination. The term 'race' remains controversial in the Norwegian setting, even thought it has a well-established meaning in the context of international law.
} 
2010). If an applicant is not granted refugee status, he or she will automatically be considered for a permit on 'humanitarian grounds' (paragraph 38), which can be granted in some instances for example because of life threatening illness or other grave circumstances, or because the applicant has a particular connection to Norwegian society.

If the legal criteria in paragraph 28 are considered to be fulfilled, there is no room for discretion in the sense that the applicant shall be granted asylum. The discretionary space in asylum decisions is related to establishing the facts of the case and determining whether the criteria are, indeed, fulfilled. In order to do so, caseworkers have to interpret ambiguous terms such as 'persecution' and 'well-founded fear' and apply them to individual cases. Moreover, applicants often lack documentation that can corroborate their stories, which makes the assessment of credibility crucial to the outcome in many cases. This constitutes one of the most difficult and contagious points in asylum decisions, because issues frequently considered to be signs of non-credibility may equally be a consequence of, for example, communication challenges, cultural differences, anxiety, and symptoms of post-traumatic trauma and stress (see e.g. Rousseau et al. 2002; Gibb and Good 2014; Herlihy et al. 2012). Another difficulty is related to the use of country of origin information. Such information is often central to determining both risk of persecution upon return, and the 'external' credibility of the story-whether the applicant's description of events is in line with 'generally known facts' (UNHCR 2011: 39). Establishing these facts is often challenging, since the country reports that caseworkers rely upon frequently contain information that is ambiguous, uncertain, and can be interpreted in many ways (Liodden 2017: Chapter 7).

The many uncertainties in the decision-making process together make up a substantial space for discretion that decision-makers have to manage in order to reach a decision. Discretion is not only exercised at the end point of the process, when the law is applied, but throughout the entire decisionmaking process (Hawkins 1992b: 14). Moreover, it is largely a collective enterprise. Together, caseworkers have to answer a number of difficult questions, such as: At what point do acts of violence and discrimination constitute 'persecution'? What does it take for a claim to be credible enough? How should ambiguous information about the applicant's home country be interpreted? When should the benefit of the doubt be applied? ${ }^{2}$

${ }^{2}$ On the benefit of the doubt, see Good (2015). 
Legal scholars conceive of discretion as a space where subjective forces enter and may threaten the rule of law-and thereby the justness of legal decisions. The legal profession has tended to see discretion as 'subjective justice; rules are formal justice' (Handler 1986: 169). From this perspective, discretion constitutes an unruly space outside of law. Arbitrary and subjective use of discretion is certainly problematic, but as Brodkin points out, discretion matters more 'not when it is random, but when it is structured by factors that influence informal behaviors to develop in systematic ways' (Brodkin 2012: 942). There are a number of 'extra-legal' factorsorganisational, psychological, political and social - that limit and order the use of discretion (Hawkins 1992b; Lipsky 2010). I am interested mainly in those factors that shape discretion in systematic ways, paying particular attention to how interviewees described the development of what they referred to as 'practice' in asylum decisions, which I will elaborate on below.

\section{Justice in Decision-Making}

In the context of administrative-legal decision-making, justice has often been used to describe the substantial outcome or accuracy of a decisionmaking process, whereas fairness has been associated with the process itself. Conceptually, they have been brought together under the term administrative justice, which encompasses both outcome and process (Sainsbury 1992: 302). This framework provides a set of goals or values that are useful to understanding bureaucratic decision-making processes. In his analysis of the asylum system in the UK, Robert Thomas argues that there are four basic goals in legal-administrative institutions that are important to quality of decisions: accuracy, fairness, cost management and timeliness (Thomas 2011: 14). There is often a trade-off between these different values, 'as any effort to promote one value will often only be capable of being achieved by moderating the achievement of other values' (Thomas 2011: 15).

It is beyond the scope of this chapter to analyse all these goals and how they are balanced in the asylum bureaucracy. In addition to timeliness, I focus on two issues related to administrative justice that became points of interest during the analysis: the notion of accuracy, and fairness in the shape of impartiality and equal treatment. ${ }^{3}$ Accuracy is related to the substantial

\footnotetext{
${ }^{3}$ Thomas (2011: 25) does not explicitly include equal treatment when he considers fairness of procedure, but he mentions it as an important goal in systems where many different decision-makers are involved.
} 
decision. It refers to establishing the facts of a case in an accurate mannerwhich in asylum decisions usually means assessing the credibility of the applicant's story-and subsequently applying the correct rules or criteria to determine the outcome. Accuracy is often described as the primary demand of administrative justice, since 'no matter what other desirable attributes a decision-making process might embody, its decisions are unlikely to be acceptable if they are wrong' (Sainsbury 1992: 302). In the words of one caseworker: 'That should be the essence in what we do. That we make the right decisions'. Despite the importance of accuracy to just decision-making, it is often an issue that is very difficult to determine in asylum cases, where decisions often revolve more around the facts than the law, and where the assessment of evidence often involves substantial uncertainty (Thomas 2011: 13). A decision can be legally sound, but it is hard to know whether the facts are correctly assessed. For asylum decisions, there is 'no external, objective standard against which to assess their accuracy' (Thomas 2011: 70). Decisionmakers rarely receive reliable feedback on their decisions; moreover, since asylum assessments are geared towards future risk, they are 'essentially an essay in hypothesis, an attempt to prophesy what might happen to the applicant in the future' (Goodwin-Gill and McAdam 2007: 54).

Equal treatment is not related directly to the substance of the decision, but to ensuring that one individual is not treated unjustly as compared to others, embodied in the notion that one should ' $\mathrm{t}$ ] reat equal (like) cases equally (alike), and unequal (different) cases unequally (differently)' (Carr 1981: 211). The principle of equal treatment presumably ensures consistent decision-making, i.e. that the outcome of cases should be relatively similar, regardless of who the decision-maker is. While consistent decision-making does not ensure accuracy-it is entirely possible for decisions to be fully consistent, yet substantially wrong-inconsistent decision-making is often considered a symptom of inaccurate decisions: '[I]f a decision-making process produces disparate outcomes, then surely some of its decisions must also be substantively incorrect-either because genuine claims have been rejected and/or non-genuine claims accepted' (Thomas 2008: 490). Studies from other contexts indicate that consistent decision-making is a major difficulty in asylum assessments, as different decision-makers appear to reach different conclusions in similar claims (Ramji-Nogales et al. 2009; Rehaag 2012; Riedel and Schneider 2017). Inconsistent decision-making challenges the idea of refugees as a clear-cut category. As Whyte (2015: 156) writes:

Refugee status is a right, conferred on appropriate persons, not something to be bartered for. This formal understanding of refugee determination is largely 
fictional, as actual refugee determination procedures vary dramatically across space and time, resulting in much more uneven implementations of who are actually recognised as refugees than the rights-based ideal.

The idea of "the refugee" as an objective identity remains strong in the public debate about asylum and bolsters the perception of a just system where distinctions between refugees and non-refugees can be clearly made. In the following sections I will, however, suggest that who a refugee is to some extent may be settled among decision-makers who together develop a local yardstick of what a just decision looks like. The present study indicates that this was achieved in part through comparison of cases and a focus on equal treatment.

\section{Equal Treatment: Creating Local Justice?}

Some caseworkers considered the uncertainty involved in the decisions to be one of the most difficult aspects of the job: 'The uncertainty is the hardest part. That you sort of never get a final answer about whether what you've been doing for the past five years is right or wrong'. Similarly, one caseworker said that 'in our work, we never get a certain answer, we never know if what we do is right or wrong, if we make the wrong decision, nobody tells us, if we reject, we never hear about it again'. In a context of uncertainty, where many decisions were emotionally difficult, equal treatment was a form of justice over which caseworkers had a measure of control:

Researcher: What do you think, our asylum politics are often referred to as strict, but fair. Do you think that's a good description of the situation?

Caseworker: Yes. Our policies are definitely not among the most liberal, if you compare with other countries. So in that way you could say that it's strict. If it's fair depends a bit on the point of view. We try to be fair in what we do, in the sense that we have a principle of equal treatment, but if it's fair that we do not admit families with children who are in a difficult position [...]. I mean, that's an impossible question to answer.

This caseworker's view of fairness is here primarily connected to equal treatment-whether the decisions are fair more broadly is an issue that she is reluctant to go into. In addition to equal treatment, impartiality was a value caseworkers emphasised when they spoke about making correct decisions. Like several other interviewees, the decision-maker above referred to 
the fact that her role was to implement law and policy, which also entailed making decisions she did not necessarily agree with. Making the right decision seemed to many caseworkers to be closely related to their identity as neutral bureaucrats who followed the rules in an impartial manner, thus echoing classical ideas connected to the ethos of bureaucracy (Weber 1978; Du Gay 2000). As in other studies of bureaucracy, caseworkers tended to emphasise the clear boundaries between policymaking and administration (see e.g. Eggebø 2013; Wettergren 2010), which meant that their personal opinion about the justness of the decision did not—and should not—affect their work.

The role of the law was ambiguous. On the one hand, caseworkers frequently referred to the law as a point of reference regarding whether or not they made the right decision. Drawing on the authority of law is probably particularly important in a field where decisions are emotionally and morally challenging, and their correctness is frequently under dispute. On the other hand, the legal framework often seemed to provide limited guidance in the actual decision-making process, apart from narrowing the scope of eligibility. Most caseworkers I spoke to were not educated in law and did not engage actively with the legal framework (see also Eule 2014: 54; Dahlvik 2014: 157). Moreover, as already mentioned, many decisions revolve around establishing facts rather than legal issues. In the words of one caseworker: 'There is nothing in the law that we can use in a decision'. She also points to equal treatment as a proxy for a just decision when accuracy is difficult to determine:

We refer to the law. Every time someone asks us or criticises us: it's the parliament that has passed the law. But the law only says that those who deserve asylum should be granted asylum, those who do not deserve it, should not be granted asylum, that's what the law says [...]. So then [it comes down to] our practice notes, how we've treated previous cases. In that way, it's equal treatment. But whether we are right - who knows?

The legal definition of the refugee narrows the scope of eligibility. You cannot, for example, be granted asylum on the basis of dire poverty or illness. Because there is such a large discretionary space, however, caseworkers had to find additional means to distinguish between eligible and non-eligible applicants.

Caseworkers did this by developing a common understanding of the assessment of cases, referred to as 'practice' in the quote above. Notes that describe current practice in the assessment of cases in the UDI constitute 
binding guidelines for caseworkers. They describe the most common reasons for seeking asylum for applicants from a particular country and how such cases normally are assessed, given interpretations of the law and country information (see e.g. UDI 2016). ${ }^{4}$ Simply put, the legal 'practice' of a public institution is made up of similar decisions in a specific field, which serve as precedents in subsequent assessments. Practice is considered to be a formal source of law, below the legal framework and preparatory works in the legal hierarchy, that may guide the interpretation and application of general rules and legal provisions (Boe 2010: 145). The importance of practice for understanding the outcome of cases will depend on how much discretion there is. In situations where there is a large degree of discretion, such as in the field of asylum, there is potentially considerable scope, both for the political level and decision-makers at the street-level, for influencing the development of practice and thereby the outcome of many asylum cases.

Practice could not, however, be understood merely by reading the notes and the formal texts they were based on. It also appeared to involve a degree of tacit or experience-based knowledge that caseworkers shared, but which was difficult to put into words (see also Jubany 2011: 87). This tacit knowledge depended on knowledge of previous assessments, close communication with colleagues, and trust in their judgments. Caseworkers considered decision-making as a practical skill that had to be acquired through hands-on experience. Over time, they seemed to acquire a 'sense of outcome' (analogous to the intime conviction that Kobelinsky discusses, this volume) that—at least in part—appeared to be based on recognising patterns in the case that were similar to or departed from previous ones. In this context, too, equal treatment was a central principle in determining the correct outcome. By comparing cases and looking to the assessment of similar cases in the past, caseworkers established a common understanding of what a rejection or an acceptance looked like.

This understanding appeared to differ somewhat from one unit to another. Such differences became particularly visible when caseworkers from time to time moved from one unit to another, or helped out with the caseload in a different unit than the one they normally worked in. This quote illustrates the perception of such differences:

Caseworker: Practice probably differs a bit for different countries. I know that on some countries, they have a totally different approach, it's sort of: 'This might have happened', and then they accept the case. There are cultural differences between the units.

${ }^{4}$ Author's translations from Norwegian. 
Researcher: Yes, why do you think that is? It's perhaps difficult to say.

Caseworker: I don't know. But the culture in different units is really different. A uniform practice... No. It depends on which interviewer you meet and what caseworker you get.

This caseworker suggests that what is considered to be credible or not, differs between units. Some are stricter whereas others are more lenient. In a recent study of the asylum bureaucracy in Norway, the researchers similarly concluded that the 'threshold of what is considered to be credible, seems to differ in different units' (Bollingmo et al. 2014: 97). ${ }^{5}$ They suggested that the variation could probably be explained by the different nature of the cases that units handle, but they also considered structural and cultural difference between the units to be important.

The development of differences may be a consequence of what Emerson has referred to as case-set effects (Emerson 1983). While most research on decision-making takes the individual case as the point of departure when considering outcomes, decision makers tend to 'respond to cases in relation to, or as part of, some larger, organisationally determined whole' (Emerson 1983: 425). Asylum decision-makers often encounter many similar claims. Making many similar decisions tends to produce shorthand ways of dealing with and classifying cases (Hawkins 1992a: 40). Comparison of similar cases within a caseload and with decisions in the past was an important tool in the assessment. For example, one caseworker said that she sometimes took a pile of cases with claims from the same country and categorised them. She tended to establish the clear rejections first. Once they had been established, it was easier to assess the rest. The advantage, she said, was that:

You work faster, at least. It's more efficient. You treat like cases alike. You have a better chance to compare the cases and you establish a kind of, well, gut feeling where you see the outcome much faster.

This approach entails that the outcome of one individual case will depend in part on the nature of the other cases in the portfolio. For example, Emerson points to studies where criminal offenses are perceived as more or less serious depending on the other cases to which officers or legal administrators are accustomed. Similarly, the evaluation of risk in an individual case may be influenced by the comparison with cases where the risk is much more severe (see also Bailliet 2003: 183). The characteristics of other cases may

${ }^{5}$ Author's translations from Norwegian. 
contribute to slightly shifting the thresholds of persecution or perceived risk among caseworkers in one unit compared to those in another unit, who are exposed to different kinds of case sets. The same is likely to be true of credibility assessments. Having assessed many cases with similar claims, caseworkers may establish an image of what a credible applicant looks like. When more, similar cases come along, they will probably have to live up to that standard — or an even higher standard — in order to be considered credible. If many cases follow the same pattern, it will take increasingly more for a case to appear convincing, because it will come across as generic and fabricated if it does not appear in a shape that underscores a personal or authentic dimension not encountered previously. At the extremities of the scale-very clear-cut rejections and very clear-cut acceptances-case load effects presumably have less impact. It seems likely, however, that cases in the grey zone in the middle of a scale, which could potentially 'land' on either side of the line, will be affected by the features of the cases at the extremities. The outcome in individual cases may therefore be substantially influenced by the caseload as a whole and the sequencing of cases.

A locally created yardstick of what the right decision looks like, based on comparison, produces consistency at a local level, but such consistency potentially co-exists with a great deal of variation across different units. Thus, due to the continuous influence of past decisions and the emphasis on equal treatment, discretion does perhaps not so much create subjective justice, but rather produces a kind of local, comparative justice (Feinberg 1974).

\section{The Production of Cases}

It is inherently difficult to find ways of assessing the quality and accuracy of decisions that involve a large degree of discretion, particularly when organisational goals are ambiguous or conflicting (Lipsky 2010: 49). Measuring productivity and timeliness can be monitored much more easily. From 1998, as part of a New Public Management trend in the Norwegian welfare state, the government began to introduce goal and result measures to increase the performance of the UDI (Christensen et al. 2006: 128). Unit leaders have to report regularly on the 'production' of cases, both to their leaders in the UDI and to the Ministry in charge. Making accurate decisions has to be balanced against the fact that the resources available for each decision are not unlimited, and against the need to produce timely decisions. Caseworkers are instructed to make decisions that are, according to the quality 
guidelines for decision-making, 'good enough', which means striking a balance between acceptable quality and efficiency (UDI 2010). Several caseworkers were concerned that the focus on production could potentially affect the quality of decision-making: 'They should really take seriously that this is a knowledge-based organisation. We don't produce tyres or tooth brushes. It's actually dangerous if we make mistakes'. Some caseworkers said they felt as though the pressure was increasing, while the resources and recognition they received from the organisation were diminishing. At the same time, the 'production' of cases is a tangible goal that caseworkers could strive for in a context where much else was uncertain. For example, this unit leader focuses on production goals when she is asked about uncertainty over the outcomes of decisions:

Researcher: Would you say that the majority of cases from [country X] are quite easy to assess, that it's quite clear whether it's an acceptance or a rejection?

Caseworker: Yes, it's become more difficult now since we no longer have the general prohibition of return, but I would say that in most cases it is possible to reach a decision within the set time limits. It's eight days after the interview. It's quite tough, but it's possible. The backlog that we've had in our unit has been a disruptive factor.

Instead of considering the content of the decision-and whether or not there is uncertainty - she emphasises the fact that more difficult cases challenge the ability to reach a decision within the set time frame. Focus is shifted from the content to the context of decision-making, where production is central. Another caseworker described the assessment of cases from a specific country as 'navigating in the dusk', because there was so much uncertainty about the outcome. Because there was very limited and unreliable country information and most cases were different from each other, it was difficult to establish a common practice that could guide the assessments and thus provide a sense of whether the outcome was right or not:

It's difficult for two reasons: First of all, it's difficult to know whether you've reached the right decision. That's one thing, and the other thing - which for many of us is the most bothersome-is that these cases are very time consuming, and there is no one in this organisation who understands that. You're measured on production. And if you have a case that you can deal with in two hours, while I am on a case where the interview has stretched over several days, it takes three weeks to find out what to do-then there's no understanding of that. So workwise, that really sucks. 
Because she navigates 'in the dusk', it is difficult to know whether she is making the right decision. But it is a reality that is difficult to change: there is no certain answer. This concern seems to become almost secondary to the pressing issue of production. Difficult cases that involve uncertainty about the outcome are time consuming. If she spends a lot of time on a case, this undermines her productivity. Hence, it is not the uncertainty around the accuracy of the decision that is the most difficult, but the fact that these kinds of decision increase work pressure. To some extent, production goals shift attention from the substance of decisions to the efficiency of the process. It can be seen as a classic example of goal displacement, where the need to process cases quickly becomes an end in itself (Lipsky 2010: 44).

\section{Deferred Justice? The Role of the Immigration Appeals Board (UNE)}

Appeals mechanisms are a means of increasing the likelihood of accurate decisions, thereby enhancing administrative justice (Sainsbury 1992: 319). If an asylum claim is rejected by the UDI, the decision can be appealed to the Immigration Appeals Board (UNE). Moreover, if the two institutions treat cases systematically differently, the UDI will usually align its practice with that of the UNE (UDI 2010). To individual caseworkers, one of the most important functions of the UNE appeared to be that it contributed to alleviating doubt and uncertainty about the accuracy of decisions. Interviewees found comfort in the fact that the UNE would correct potential mistakes, thus redressing potential injustices. This is in line with other studies that describe how decision-makers feel reassured by the fact that someone else will make a second assessment (Dahlvik 2014; Baillot et al. 2014: 533), deferring 'responsibility for the final outcome to another superior body or role-player' (Baillot et al. 2014: 535). In the words of one caseworker: 'There is the appeal. Sometimes I have to tell myself that: there is actually the possibility of appeal'. In Carlsen's (2011) study of the UDI, one interviewee points to the idea that the notion of 'deferred' justice may allow caseworkers to work more efficiently: 'We've termed it "risk control"-it means that our bosses accept that we make mistakes in case processing. The idea is that as long as we keep up a certain efficiency, potential mistakes will be corrected during the appeal' (case worker cited in Carlsen 2011: 82). ${ }^{6}$

${ }^{6}$ Author's translation from Norwegian. 
In an interview, I spoke to a caseworker about a change in country information, which now corroborated many applicants' credibility instead of undermining it. When I asked her how she felt about the previous decisions-when asylum seekers perhaps had been wrongly rejected-she said that she took comfort in the fact that by the time these cases were processed in the UNE, they too would have updated their information and would correct the decisions:

It's no fun to think about the cases that...we've probably rejected a few cases that according to this [new practice] would have been accepted. And then you have to think, okay, but those cases still have not been treated at the UNE, and the UNE will update their practice.

As a means to address the problem of the time lag between country information and development on the ground, the appeal plays an important role. It may, however, be problematic to rely too much on the appeal for an independent assessment in difficult cases. Bailliet (2003) found that some caseworkers tended to reject cases when they were unsure about how to resolve a complex issue, assuming that the applicant would appeal the case to the UNE. Caseworkers then expected the UNE to provide a signal to the UDI about how such cases should be solved. She comments: 'This tactic does not always prove successful in those cases in which the UNE Secretariat adopts the same language and argumentation utilised by the UDI with little variation' (Bailliet 2003: 169). In fact, a relatively limited number of decisions are changed upon appeal. In 2016, the UNE overruled $8 \%$ of UDI's asylum decisions; for 2015 , the number was $16 \% .^{7}$ When decisions are not overturned, this too serves as a form of feedback, suggesting that decisions are correct. According to the caseworker in the following quote, the UNE usually overrules UDI decisions because of changes in circumstances. With more than ten years of experience as a decision-maker, she could not recall a single case that had been overturned due to a different credibility assessment:

Researcher: If they [UNE] change a decision in one of the cases you've assessed-what do you think then?

Caseworker: That usually happens because a lot has changed during the appeal process. New information, that the applicant has become ill. It's

${ }^{7}$ See: https://www.une.no/statistikk/asylsaker/ [Accessed 24 July 2017]. 
usually in those cases-psychological illness, serious physical illness- that the UNE changes the decision. Or due to changes in the situation of the country of origin $[\ldots]$

Researcher: So it's quite rare that they overturn your credibility assessments?

Caseworker: I don't think I've seen that.

Researcher: So it's quite similar [...]

Caseworker: I think they are stricter than us. I think so.

This lends support to the idea that credibility 'sticks'-once lack of credibility has been established, it can be difficult to rebut (see e.g. Coffey 2003). One reason for this may be that much of the indeterminacy has been dealt with before the case reaches the UNE. Many of the discretionary decisions that caseworkers make during the process of assessing asylum cases can be considered 'second order decisions' (Hawkins 1986). They are numerous, but often invisible by the end of the process. Second order decisions 'may not seem to be particularly significant, such as what information should be included as part of the raw material of a case, but they may have enormous implications for how subsequent primary decisions are made' (Hawkins 1986: 1166). By contrast, 'first order decisions' are the salient, visible decisions in the career of a legal case-such as the status as an accepted or rejected applicant. The numerous second order decisions that caseworkers in the first instance make about information processing and interpretation are not visible in the documents that the UNE receives, but they may nevertheless contribute to constructing the case in a particular manner. Perhaps more importantly, most UNE decisions are made on the basis of documents only; in 2016, applicants were given the opportunity to provide oral testimony in 4\% of cases (UNE 2017: 18). As Sainsbury (1992: 304) points out, one of the most important ways of addressing the challenge of incomplete, contradictory or unclear evidence is to actively involve claimants in the information collection process. It is presumably much more difficult to justify changing a credibility assessment when the decision-maker at appeal has not heard the claimant giving evidence in person. While decision-makers in the UDI trusted the UNE to correct potential mistakes, it is possible that the limited number of oral hearings challenges the UNE's ability to make truly independent decisions. This, in turn, may affect the UNE's capacity to redress potential injustices. 


\section{The Media Debate: Criticism and the Production of Certainty}

The public debate in the field of asylum is a source of critique that can lead to deliberation about the justness of current practices and the accuracy of decisions. In a field where it is difficult to know whether decisions are accurate or not, such critique can be considered one of the few sources of feedback. Interviewees varied in their perception of the media debate; some found it interesting and enjoyed working in a contested field while others considered it a source of stress. They had in common, however, that critique in the media rarely was seen as indicative of whether or not cases were assessed correctly. For one thing, there is no consensus in the public debate. Caseworkers are sometimes criticised for being too harsh-at other times, for being naïve and too lenient. Moreover, criticism was often considered misguided and based on emotions instead of knowledge of the rules. Knowing the process from the inside changed the perspective: It meant understanding the constraints under which the work was conducted, the criteria that must be fulfilled, and the details that could produce different outcomes in two seemingly similar cases. Only work peers were fully able to understand the wide range of considerations in the assessments.

Several caseworkers appeared to feel that it was important to shield themselves from the emotional climate in the media debate, which could threaten the impartiality required to assess cases in a just manner. They emphasised the importance of non-responsiveness to external pressures (Lindberg 2013: 217). If caseworkers were to become too affected by issues raised in the media, it could potentially conflict with their political and legal accountability as impartial implementers of law and policy. The media's tendency to focus on specific individuals could in itself be viewed as a potential source of injustice. ${ }^{8}$ In this context, 'justness' was largely equivalent to treating like cases alike, and did not entail an evaluation of the decisions more substantially. The justness of the system more broadly was considered a political matter, since, in the words of one interviewee, 'we don't decide, we implement'. It followed that the target of critique should be the political level and not those in charge of policy implementation. Making an exception because of

\footnotetext{
${ }^{8}$ The most striking example that several caseworkers mentioned was the case of Maria Amelie, an exceptionally articulate, well integrated young woman whose asylum application had been rejected. The deportation of Amelie created public outrage and evoked broad sympathy across the political spectrum. Several caseworkers mentioned that with their knowledge of practice, they found the intense focus on Amelie to be highly unjust to other applicants.
} 
media attention might be possible within the scope of the law, particularly in cases concerning permits on humanitarian grounds, where legal discretion is rather large. ${ }^{9}$ According to established practice, however, such exceptions would violate the norm of equal treatment and therefore be highly unjust to other applicants who might have been rejected under much more dire circumstances.

The nature of the asylum assessments may serve as a potential buffer against criticism in itself. Modern bureaucracy has been criticised for the fact that the complexity of the system makes it difficult to establish a clear link between action on the part of any one individual and the outcome or consequences of their actions (see e.g. Bauman 1989). The consequence of a rejection in asylum cases may be particularly diffuse. For one thing, as noted, asylum assessments are directed toward future risk and are thereby hypothetical by nature. Moreover, the facts of many cases are unclear and under disbelief, rendering the consequences of a rejection even more elusive and difficult to imagine. Applicants whose stories are portrayed in the media and who have been rejected due to lack of credibility are by definition not trustworthy sources and the lack of reliable feedback means that decision-makers rarely find out if they make mistakes. The importance of establishing a link between a decision and its potential consequences may explain why several caseworkers appeared to feel that the greatest injustice was done in cases concerning humanitarian protection that were rejected. In these cases, there was usually no question about the accuracy of facts. The adverse consequences of return to the home country were often rather straightforward-clearly exposing the relationship between a negative decision and its consequences. Cases concerning health issues, in particular those involving children, spurred the greatest sense of injustice in some of the interviewees, to the point where some of them questioned the legitimacy of the legal categories (compare to Gianopoulou and Gill, this volume). For example, one caseworker considered some of these rejections to be 'unreasonable', 'horrible' and 'grossly unjust'.

In an interview, one caseworker said: 'We are very certain of ourselves. And I believe that's because we are never told that we make mistakes'. She added: 'I sit here and do this day after day, I am never told that there are mistakes, only that this is correct. Then you become more and more certain that what you are doing is right'. These statements may at first sight seem puzzling, considering the frequent debate about asylum decisions in

\footnotetext{
${ }^{9}$ Note, however, that decision-makers are subject to political instructions in cases concerning humanitarian protection. These instructions limit their scope of discretion, but there is nevertheless some leeway, depending on the country of origin and the nature of the claim.
} 
the public sphere. The caseworker does not refer to lack of debate in general, however, but to the fact that the immigration authorities rarely admit to mistakes in public. There is a striking contrast between the uncertainty that goes into the assessment of asylum cases, and the certainty with which politicians and representatives of the institution talk about asylum decisions in public. The following quote from the former head of UNE, Terje Sjeggestad, serves as an illustration: 'Luckily, the UNE is not aware of a single documented example of the fact that we have returned someone to persecution' (Stavanger Aftenblad, 18 November, 2010). The remark may not be representative for the UNE's stance in general, but there are strong incentives for the asylum bureaucracy to present outward certainty. The complexity of refugee determination calls for the confidence to make decisions that may have fatal consequences if they are wrong (Luker 2013: 514). The display of outward certainty is presumably important to bolster the confidence and morale of decision-makers, as well as signaling justness to the public.

The need to maintain certainty about decisions can paradoxically be an impediment to attempts to monitor their accuracy. There are occasional public claims about asylum seekers who have been subjected to torture or death upon return, but there is no system for monitoring rejected applicants in Norway. In a written response to a request about monitoring after return, the Norwegian Ministry of Justice replied:

The situation upon return has been assessed when a decision has been made to reject a case. The Norwegian immigration authorities consider that in each case, the assessment of protection and the rule of law should be at a standard that makes it unnecessary to monitor whether or not someone who has been returned will be subjected to persecution (Anundsen 2015). ${ }^{10}$

In this quote, dismissing the need for monitoring is equivalent to expressing confidence in the assessments and the rule of law. In an interesting parallel, the Netherlands attempted to monitor returnees to Iran at one point in the 1990s. According to a Dutch country advisor, the monitoring desisted in part because Iranian authorities disapproved, but also because monitoring could 'leave the impression that Dutch authorities did not trust their own assessments'. ${ }^{11}$ Monitoring may signal uncertainty that contributes to undermining belief in a just system.

\footnotetext{
${ }^{10}$ Author's translation from Norwegian.

${ }^{11}$ E-mail from country advisor in Dutch country of origin information department, March 30th 2011 (Landinfo 2011: 2). Author's translation from Norwegian.
} 


\section{Discussion}

The institution of asylum is a powerful tool of protection and a symbol of a nation's adherence to human rights; however, the institution also serves as a gatekeeper to the nation and is an effective tool of exclusion of those not considered eligible. For exclusion to be acceptable, it must be done on legitimate grounds. This becomes particularly urgent in a policy field where negative decisions often entail high human costs, such as deportation and detention. For example, the media regularly brings up deportations of families, focusing particularly on children. The communication of legality and certainty alleviates the moral discomfort connected to the consequences of asylum politics. The clear-cut distinction between genuine refugees and others who do not have eligible grounds for protection plays an important role for the public acceptance of asylum politics and the perception of such politics as 'strict, but just', which has been the slogan to varying degrees in Norway for the past several years.

The idea of the refugee as a clear-cut, objective identity is reflected in the language surrounding refugees. We speak of 'refugee recognition' as if it were an identity that is objectively present among certain individuals that simply needs to be uncovered. The status is 'declaratory', which means that someone 'does not become a refugee because of recognition, but is recognised because he is a refugee' (UNHCR 2011: pt. 28). Public expectations about justice appear to be based on this idea of clearly demarcated individuals, whose rights are being fulfilled according to the law. In many asylum cases, however, the question is not primarily about the law, but about facts. During the decision-making journey, a legal decision constitutes the final destination, but the law often does not provide much guidance on the way.

A more accurate description is perhaps that refugees are defined into being in the encounter with the host states, and more specifically, during the refugee determination procedure (see also Stevens et al. 2014; Zetter 1991). Decision-makers participate in the negotiation about the boundaries of the refugee category daily in their work. The many uncertainties that often characterise decision-making, combined with the specialised knowledge of decision-makers, open up a discretionary space that is difficult to control from above and is shielded from public view. Like other street-level bureaucrats, caseworkers not only implement policy, they also shape it in important ways. They try to answer many complex questions in a context where they are under time pressure, there is limited or ambiguous information, they receive scarce reliable feedback, and the decisions can be emotionally difficult. While decision-makers refer to the same legal framework, they develop 
local norms through the comparison of cases that serve as a yardstick for what the eligible refugee looks like. It is, however, difficult to know how this yardstick relates to external reality, particularly in case portfolios where credibility assessment is central to the outcome. Equal treatment, or 'following the same practice', can be considered to become a proxy for justice in a context where it is hard to evaluate the accuracy of decisions. Such consistency at a local level may, however, easily co-exist with inconsistencies on a broader level documented by research in other countries (see e.g. RamjiNogales et al. 2009; Rehaag 2012; Riedel and Schneider 2017). To some extent, then, justice becomes locally produced.

While decision-makers appear to become more confident in their decisions with experience, they do not necessarily make more accurate-or just-decisions over time, particularly when there is lack of reliable feedback. Considering the psychological cost of doubting previous decisions in asylum cases, where the stakes are exceptionally high, it is even possible that experience may increase self-confidence at the expense of self-scrutiny. An institution that is constantly under criticism is perhaps less likely to provide an environment that encourages deliberation about the justness of its decisions. It seems, however, to be of vital importance to open up such 'critical spaces' (Crépeau and Nakache 2008), if not in public, then at least internally. In a situation where there are no clear answers, engaging with the uncertainty and doubt that are inevitably there, may be the best way of improving the conditions of just decision-making.

\section{References}

Anundsen, A. (2015). Skriftlig spørsmål fra Karin Andersen (SV) til justis- og beredskapsministeren. Available at: https://www.stortinget.no/no/Saker-ogpublikasjoner/Sporsmal/Skriftlige-sporsmal-og-svar/Skriftlig-sporsmal/?qid= 61658. Accessed 6 Jan 2015.

Bailliet, C. (2003). Study of the Grey Zone Between Asylum and Humanitarian Protection in Norwegian Law and Practice. Available at: https://www.jus.uio.no/ ior/personer/vit/ceciliab/dokumenter/KRD-rapport.pdf. Accessed 20 July 2017.

Baillot, H., Cowan, S., \& Munro, V. E. (2014). Reason to Disbelieve: Evaluating the Rape Claims of Women Seeking Asylum in the UK. International Journal of Law in Context, 10, 105-139.

Bauman, Z. (1989). Modernity and the Holocaust. Cambridge: Polity Press.

Boe, E. (2010). Grunnleggende juridisk metode - en introduksjon til rett og rettstenkning. Oslo: Universitetsforlaget. 
Bollingmo, G. C., Skilbrei, M.-L., \& Wessel, E. (2014). Troverdighetsvurderinger: Søkerens forklaring som bevis $i$ saker om beskyttelse (asyl). Available at: https://www. udi.no/globalassets/global/forskning-fou_i/beskyttelse/troverdighetsvurderinger-sokerens-forklaring-som-bevis-i-saker-om-beskyttelse.pdf. Accessed 23 July 2017.

Boswell, C. (2005). The Ethics of Refugee Policy. Aldershot: Ashgate.

Brodkin, E. Z. (2012). Reflections on Street-Level Bureaucracy: Past, Present and Future. Public Administration Review, 72, 940-949.

Carling, J. (2011). The European Paradox of Unwanted Migration. In P. J. Burgess \& S. Gutwirth (Eds.), A Threat Against Europe? Security, Migration and Integration (pp. 33-46). Brussels: Brussels University Press.

Carlsen, C. B. (2011). Makt og motmakt i utlendingsforvaltningen. En studie av saksbehandlingskultur i UDI. Master's thesis, University of Oslo, Oslo.

Carr, C. (1981). The Concept of Formal Justice. Philosophical Studies, 39, 211-226.

Christensen, T., Lægreid, P., \& Ramslien, A. (2006). Styring og autonomi: Organisasjonsformer i utlendingsforvaltningen. Oslo: Scandinavian University Press.

Coffey, G. (2003). The Credibility of Credibility Evidence at the Refugee Review Tribunal. International Journal of Refugee Law, 15, 377-417.

Crépeau, F., \& Nakache, D. (2008). Critical Spaces in the Canadian Refugee Determination System 1989-2002. International Journal of Refugee Law, 20, 50-122.

Dahlvik, J. (2014). Administering Aslylum Applications. Dissertation, Universität Wien, Vienna.

Du Gay, P. (2000). In Praise of Bureaucracy. Weber-Organizations—Ethics. London: Sage.

Eggebø, H. (2013). 'With a Heavy Heart': Ethics, Emotions and Rationality in Norwegian Immigration Administration. Sociology, 47, 301-317.

Emerson, R. M. (1983). Holistic Effects in Social Control Decision-Making. Law and Society Review, 17, 425-456.

Eule, T. G. (2014). Inside Immigration Law. Farnham: Ashgate.

Feinberg, J. (1974). Noncomparative Justice. Philosophical Review, 83, 297-338.

Gibb, R., \& Good, A. (2014). Interpretation, Translation and Intercultural Communication in Refugee Status Determination Procedures in the UK and France. Language and Intercultural Communication, 14, 385-399.

Good, A. (2015). The Benefit of the Doubt in British Asylum Claims and International Cricket. In D. Berti, A. Good, \& G. Tarabout (Eds.), Of Doubt and Proof: Ritual and Legal Practices of Judgment. Farnham: Ashgate.

Goodwin-Gill, G., \& McAdam, J. (2007). The Refugee in International Law. Oxford: Oxford University Press.

Handler, J. F. (1986). The Conditions of Discretion. Autonomy, Community, Bureaucracy. New York: Russel Sage Foundation.

Hawkins, K. (1986). Discretion in Making Legal Decisions. On Legal DecisionMaking. Washington and Lee Law Review, 43, 1161-1242.

Hawkins, K. (1992a). The Use of Legal Discretion: Perspectives from Law and Social Science. In K. Hawkins (Ed.), The Uses of Discretion. Oxford: Clarendon Press. 
Hawkins, K. (Ed.). (1992b). The Uses of Discretion. Oxford: Clarendon Press.

Herlihy, J., Jobson, J., \& Turner, S. (2012). Just Tell us What Happened to You: Autobiographical Memory and Seeking Asylum. Applied Cognitive Psychology, 26, 661-676.

Jubany, O. (2011). Constructing Truths in a Culture of Disbelief: Understanding Asylum Screening from Within. International Sociology, 26, 74-94.

Landinfo. (2011). Iran: Returnerte asylsøkere. Oslo: Landinfo.

Lindberg, S. I. (2013). Mapping Accountability: Core Concepts and Subtypes. International Review of Administrative Science, 79, 202-226.

Liodden, T. M. (2017). The Burdens of Discretion. Managing Uncertainty in the Asylum Bureaucracy. Ph.D., University of Oslo.

Lipsky, M. (2010). Street Level Bureaucracy. Dilemmas of the Individual in Public Services. New York: Russel Sage Foundation.

Luker, T. (2013). Decision Making Conditioned by Radical Uncertainty: Credibility Assessment at the Australian Refugee Review Tribunal. International Journal of Refugee Law, 25, 502-534.

McCoy, L. (2006). Keeping the Institution in View: Working with Interview Accounts of Everyday Experience. In D. Smith (Ed.), Institutional Ethnography as Practice. Oxford: Rowman and Littlefield.

Ministry of Justice and Public Security. (2010). Act of 15 May 2008: On the Entry of Foreign Nationals into the Kingdom of Norway and Their Stay in the Realm (Immigration Act). Available at: https://www.regjeringen.no/en/dokumenter/ immigration-act/id585772/. Accessed 24 July 2017.

Ramji-Nogales, J., Schoenholtz, A. I., \& Schrag, P. G. (Eds.). (2009). Refugee Roulette. Disparities in Asylum Adjudication and Proposals for Reform. New York: New York University Press.

Rehaag, S. (2012). Judicial Reivew of Refugee Determiniations: The Luck of the Draw? Queen's Law Journal, 38, 1-57.

Riedel, L., \& Schneider, G. (2017). Dezentraler Asylvollzug diskriminiert: Anerkennungsquoten von Flüchtlingen im bundesdeutschen Vergleich, 20102015. Politische Vierteljahesschrift, 58, 23-50.

Rousseau, C., Crépeau, F., Foxen, P., \& Houle, F. (2002). The Complexity of Determening Refugeehood: A Multidisciplinary Analysis of the DecisionMaking Process of the Canadian Immigration and Refugee Board. Journal of Refugee Studies, 15, 43-70.

Sainsbury, R. (1992). Administrative Justice: Discretion and Procedure in Social Security Decision Making. In K. Hawkins (Ed.), The Uses of Discretion. Oxford: Clarendon Press.

Smith, D. E. (2005). Institutional Ethnography. A Sociology for People. New York: Altamira Press.

Stevens, D., Kneebone, S., \& Baldassar, L. (2014). Law, Identity and Protection: Concluding Reflections. In S. Kneebone, D. Stevens, \& L. Baldassar (Eds.), Refugee Protection and the Rule of Law. Conflicting Identities. London: Routledge. 
Stortinget. (2011). Lovvedtak 22 (2011-2012). Available at: https://www.stortinget. no/globalassets/pdf/lovvedtak/2011-2012/vedtak-201112-022.pdf. Accessed 2 Aug 2017.

Thomas, R. (2008). Consistency in Asylum Ajudication: Country Guidance and the Asylum Process in the United Kingdom. International Journal of Refugee Law, 20, 489-532.

Thomas, R. (2011). Administrative Justice and Asylum Appeals: A Study of Tribunal Adjudication. Oxford: Hart Publishing.

UDI. (2010). Kvalitet $i$ saksbehandlingen. RS 2010-109. Available at: https://udiregelverk.no/no/rettskilder/udi-rundskriv/rs-2010-109/. Accessed 25 July 2017.

UDI. (2016). Asylpraksis - Iran. PN 2016-002. Available at: https:/udiregelverk.no/ no/rettskilder/udi-praksisnotater/iran-pn-2016-002/. Accessed 28 July 2017.

UNE. (2017). Arsrapport 2016. Oslo: Utlendingsnemnda.

UNHCR. (2011). Handbook and Guidelines on Procedures and Criteria for Determining Refugee Status Under the 1951 Convention and the 1967 Protocol Relating to the Status of Refugees. Available at: http://www.unhcr.org/3d58e13b4. pdf. Accessed 18 July 2017.

Weber, M. (1978). Bureaucracy. In G. Roth \& C. Wittich (Eds.), Economy and Society II. Berkeley: University of California Press.

Wettergren, Å. (2010). Managing Unlawful Feelings: The Emotional Regime of the Swedish Migration Board. International Journal of Work Organisation and Emotion, 3, 400-419.

Whyte, Z. (2015). In Doubt: Documents as Fetisches in the Danish Asylum System. In D. Berti, A. Good, \& G. Tarabout (Eds.), Of Doubt and Proof: Ritual and Legal Practices of Judgment. Farnham: Ashgate.

Zetter, R. (1991). Labelling Refugees: Forming and Transforming a Bureuacratic Identity. Journal of Refugee Studies, 4, 39-61.

Open Access This chapter is distributed under the terms of the Creative Commons Attribution 4.0 International License (http://creativecommons.org/licenses/ by/4.0/), which permits use, duplication, adaptation, distribution and reproduction in any medium or format, as long as you give appropriate credit to the original author(s) and the source, a link is provided to the Creative Commons license and any changes made are indicated.

The images or other third party material in this chapter are included in the work's Creative Commons license, unless indicated otherwise in the credit line; if such material is not included in the work's Creative Commons license and the respective action is not permitted by statutory regulation, users will need to obtain permission from the license holder to duplicate, adapt or reproduce the material.

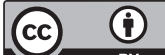

